\title{
Carotid-Cavernous Fistula Caused by Rupture of Persistent Primitive Trigeminal Artery Trunk Aneurysm -Case Report-
}

\author{
Masahiro YOSHIDA, ${ }^{1}$ Masayuki EzURA, ${ }^{2}$ and Masaki MINO ${ }^{1}$ \\ ${ }^{1}$ Department of Neurosurgery, Osaki Citizen Hospital, Osaki, Miyagi; \\ ${ }^{2}$ Department of Neurosurgery, Sendai Medical Center, Sendai, Miyagi
}

\begin{abstract}
A 60-year-old female presented with a carotid-cavernous fistula (CCF) manifesting as left abducens nerve palsy. Left internal carotid digital subtraction angiography showed a persistent primitive trigeminal artery (PPTA) near the CCF. Super-selective angiography showed direct shunt flow between the PPTA trunk aneurysm and the left cavernous sinus. The aneurysm was successfully occluded with detachable coils. The CCF disappeared and the PPTA was preserved. The abducens nerve paralysis had disappeared 6 months later. CCF caused by a PPTA trunk aneurysm is extremely rare. We speculate that the PPTA trunk aneurysm formed and then ruptured due to hemodynamic stress caused by hypoplasia of the basilar artery.
\end{abstract}

Key words: carotid-cavernous fistula, persistent primitive trigeminal artery, coil embolization

\section{Introduction}

Persistent primitive trigeminal artery (PPTA) is an embryonic communication between the basilar and internal carotid arteries, ${ }^{26}$ ) which usually arises from the presellar internal carotid artery as it exits in the carotid canal and enters the cavernous sinus, then extends posteriorly to join the distal third of the basilar artery, usually between the origins of the superior and anterior inferior cerebellar arteries. The incidence of PPTA is reported to be between $0.1 \%$ and $0.6 \%$ based on conventional angiography or magnetic resonance (MR) imaging. ${ }^{25)}$ The presence of this artery is considered to indicate a defect in cerebrovascular development and may be associated with other vascular anomalies such as arteriovenous malformations or aneurysms. ${ }^{11)}$ However, an aneurysm of the PPTA is rare. Rupture of a PPTA aneurysm can result in subarachnoid hemorrhage or carotid-cavernous fistula (CCF). ${ }^{22)}$ Such CCFs are extremely rare. We describe a case of CCF caused by a PPTA trunk aneurysm successfully treated by intra-aneurysmal coil embolization.

\section{Case Report}

A 60-year-old female presented with a 6-month history of diplopia caused by left abducens nerve palsy but no history of head trauma. MR imaging revealed dilated cavernous sinus and cortical veins (Fig. 1). Single photon emission computed tomography (SPECT) showed hypoperfusion of the left frontal lobe (Fig. 2A). Left carotid digital subtrac-

Received August 24, 2010;

Accepted December 24, 2010

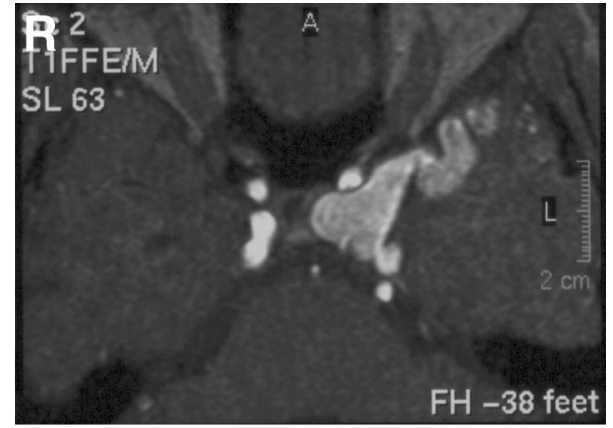

Fig. 1 Three-dimensional time-of-flight magnetic resonance image showing the dilated left cavernous sinus and cortical vein.

tion angiography showed direct flow through a CCF into the cortical veins, and a PPTA arising from the carotid artery running to the basilar artery (Fig. 3A). Vertebral angiography performed to assess left neck common carotid artery compression (Alcock test) showed retrograde filling of the PPTA and CCF (Fig. 3B). Three-dimensional digital subtraction angiography revealed an aneurysm at the curved PPTA trunk (Fig. 4).

A micro-catheter (Excelsior 1018; Boston Scientific, Natick, Massachusetts, USA) was guided into the origin of the PPTA from the left internal carotid artery, and selective injection of contrast medium demonstrated direct flow into the cavernous sinus (Fig. 3C, D). The catheter was advanced further along the PPTA and the contrast injection repeated, allowing identification of an aneurysm 

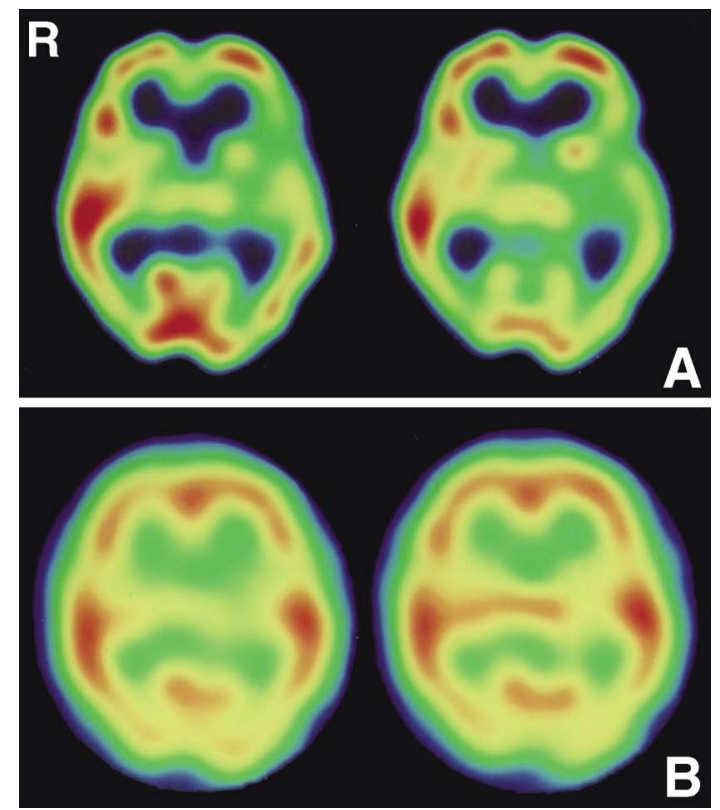

Fig. 2 Technetium-99m-ethylcysteinate dimer single photon emission computed tomography scans, before treatment (A) showing diffuse hypoperfusion in the left frontal lobe, and after treatment (B) demonstrating improved cerebral blood flow in the left frontal lobe.

arising from the anterior wall of the curved PPTA trunk, which was drained into the cavernous sinus (Fig. 3E). The aneurysm had a regular spherical shape, was approximately $6 \mathrm{~mm}$ in diameter, and had a relatively narrow neck. An attempt to pass the catheter through the fistula failed because the fistula was apparently too small. We decided to perform intra-aneurysm embolization with electrical detachable coils. After insertion of 6 Guglielmi detachable coils (total $55 \mathrm{~cm}$; Boston Scientific), the aneurysm was successfully occluded, and the CCF completely disappeared with preservation of the PPTA (Fig. 5).

The patient recovered well, and the abducens nerve paralysis showed gradual recovery, with complete resolution 6 months after the procedure. Postoperative SPECT revealed improvement of the hypoperfusion in the left frontal lobe (Fig. 2B). Postoperative MR angiography showed narrowing of the basilar artery and the posterior circulation mainly depended on the PPTA (Fig. 6).

\section{Discussion}

Only 19 cases of trigeminal carotid fistula have been reported in the English literature, ${ }^{2-10,12,14,16,17,21,22,24,28,30}$ ) and 13 of these cases were non-traumatic (spontaneous) CCFs (Table 1). The locations of the fistula were the internal carotid artery-PPTA junction in 13 cases, and the PPTA trunk in 6 . One case presented with intracerebral hemorrhage, ${ }^{28)}$ but the symptoms in others were not distinctive and included bruits, chemosis, proptosis, diplopia, retro-orbital pain, and so on. The treatment methods included ligation or direct surgery in 3 cases, ${ }^{2,6,9)}$ detachable balloons in $8,5,7,8,10,14,17,21,22)$ and coil emboliza-

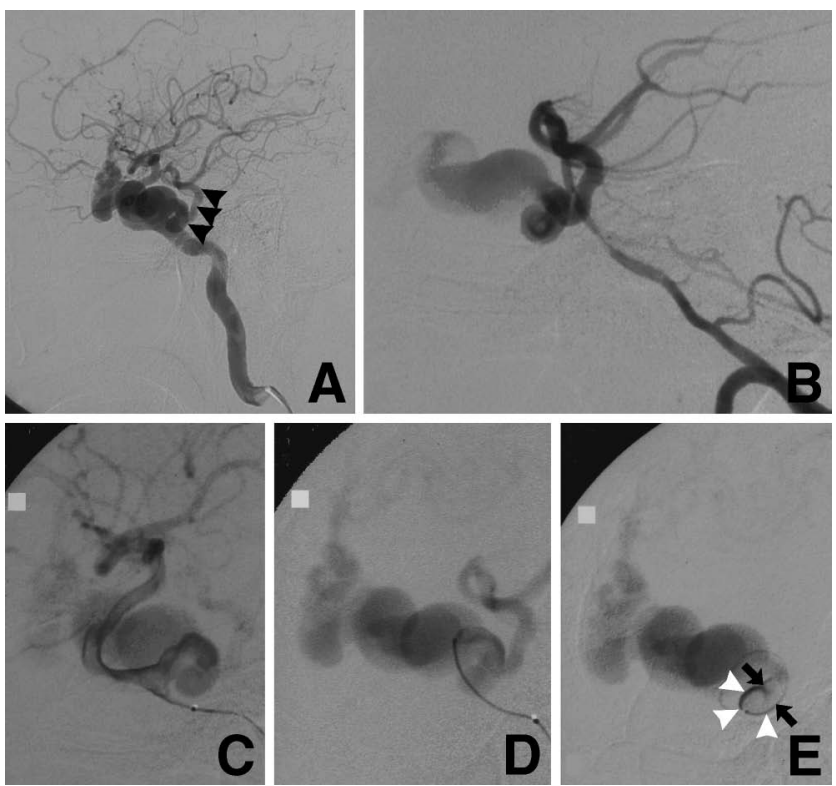

Fig. 3 Diagnostic digital subtraction angiograms. A: Left internal carotid angiogram, lateral view, showing direct high flow in a carotid-cavernous fistula (CCF) accompanied by a persistent primitive trigeminal artery (PPTA) (arrowheads). B: Left vertebral angiogram with left neck common carotid artery compression (Alcock test) showing retrograde filling of the PPTA and CCF, and severe stenosis of the middle portion of the basilar artery trunk. C, D: Super-selective angiograms from the left internal carotid artery-PPTA junction (C) and the PPTA trunk (D). E: Aneurysmogram showing the aneurysm arising from the anterior wall of the curved PPTA trunk, and then flowing out to the cavernous sinus. The diameter of the aneurysm was approximately $6 \mathrm{~mm}$ (arrowheads), and the neck was relatively narrow (arrows).
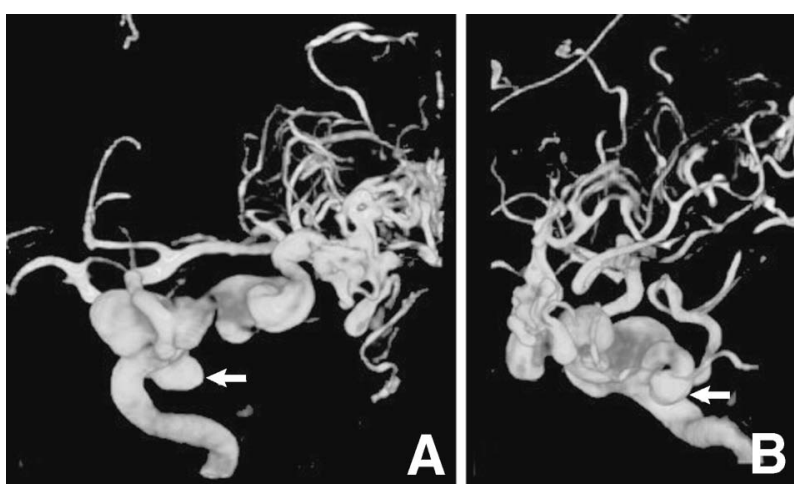

Fig. 4 Preoperative anteroposterior (A) and lateral (B) threedimensional digital subtraction angiograms showing persistent primitive trigeminal artery trunk aneurysm (arrow).

tion in $7 .^{3,4,12,16,24,28,30)}$ This disorder has been treated mainly by endovascular approaches since the 1990s. The present case of CCF caused by a PPTA trunk aneurysm was treated with intra-aneurysmal coiling. The 14 cases described as spontaneous CCFs, including our present 

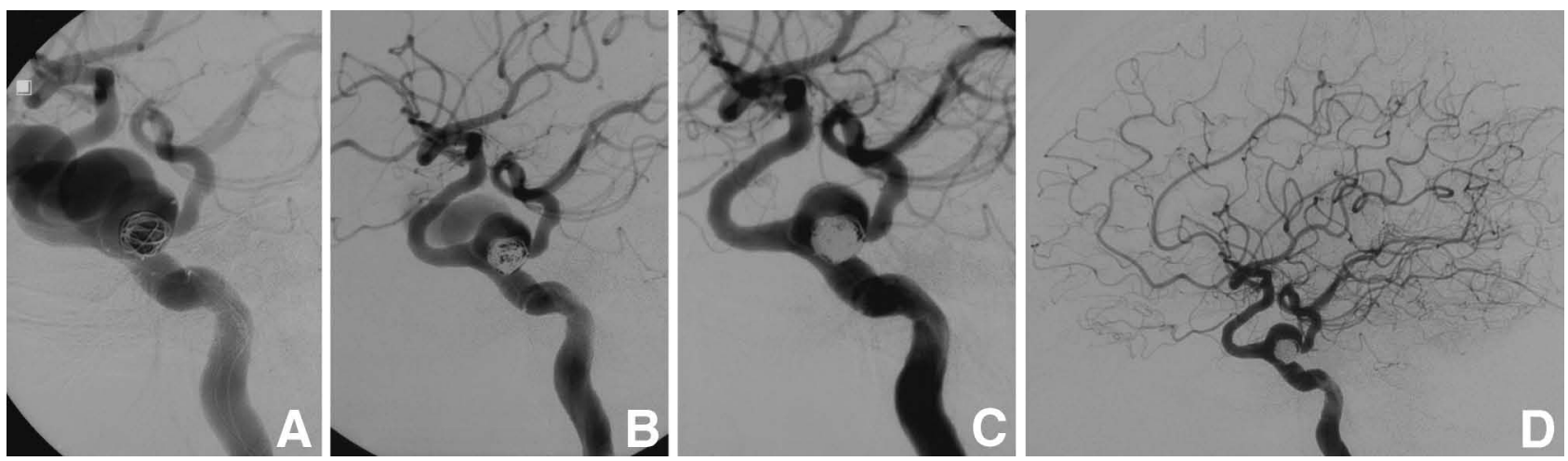

Fig. 5 Digital subtraction angiograms performed during intra-aneurysmal embolization just after insertions of the first coil (A), the third coil (B), and the sixth (last) coil (C). The aneurysm was successfully occluded, and the carotid-cavernous fistula completely disappeared with preservation of the persistent primitive trigeminal artery (D).
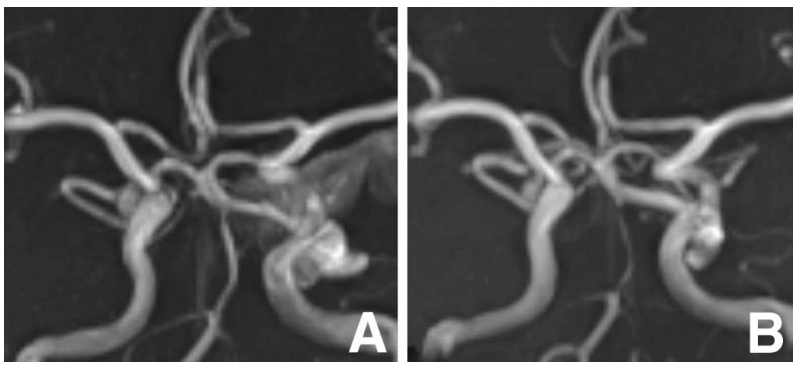

Fig. 6 Pre- (A) and postoperative (B) magnetic resonance angiograms showing disappearance of the carotid-cavernous fistula and preservation of the persistent primitive trigeminal artery. The basilar artery seems to be hypoplastic.

case, may have been caused by rupture of a PPTA aneurysm, although aneurysms were detected on angiography in only 4 cases. The etiologies may be similar to those of CCFs caused by rupture of a cavernous aneurysm (Barrow type AII). ${ }^{1)}$

Generally, the first choice of treatment for direct CCF is considered to be detachable balloon embolization. ${ }^{19)}$ The transarterial approach is recommended for balloon embolization, and also usually recommended for coil embolization except in cases of Ehlers-Danlos syndrome with fragile arterial walls. ${ }^{13,18)}$ Transarterial intra-aneurysmal embolization often effectively occludes the fistula. ${ }^{23)}$ Coiling of the aneurysm with balloon protection was reported recently, and apparently provided favorable results in terms of fistula closure and precise preservation of the patency of the parent artery. ${ }^{15)}$ Transvenous cavernous sinus packing with detachable coils may require a large volume of coils and carries the risk of ocular symptom exacerbation, ${ }^{15,24)}$ but is considered a good choice if a transarterial approach is difficult. ${ }^{18)}$ A major disadvantage of coiling is the high cost. Thus, from the standpoint of costeffectiveness, aneurysm coiling might be preferable to sinus packing. ${ }^{23)}$

The strategies we considered before treating this patient were embolization with a detachable balloon, trapping of the PPTA with coils, trans-arterial trans-fistula sinus packing with coils, trans-venous sinus packing with coils, and intra-aneurysmal coil embolization. Balloon embolization would have been too difficult because the parent artery was extremely tortuous and the fistula was quite small. Furthermore, detachable balloons are difficult to obtain commercially in Japan. ${ }^{18)}$ PPTA is often associated with hypoplasia of the basilar artery, so trapping of the PPTA would have been technically feasible but not desirable in this case. The trans-arterial trans-fistula approach was also difficult due to the small fistula. Since transvenous sinus packing would require a large volume of coils, intraaneurysmal embolization was the simplest treatment strategy available.

Super-selective angiography and aneurysmography facilitated our understanding of the morphology of the aneurysm. Vertebral angiography with ipsilateral carotid compression (Alcock test) was also useful for ascertaining the relationship between the PPTA and the fistula. Fortunately, the aneurysm was easily treated. The aneurysm was spherical and had a narrow neck, so we were able to occlude the fistula without difficulty. The internal carotid artery and the PPTA were preserved. If the neck had been wide, we would have adopted a balloon assist technique. ${ }^{29)}$ We maintained the posterior circulatory blood flow, and SPECT revealed improved cerebral blood flow at the area of venous reflux. The findings of three-dimensional digital subtraction angiography were complicated, but this diagnostic procedure was very useful for measuring the diameter of the aneurysm at the time of selecting the first coil.

Various etiologies for aneurysms arising from the PPTA have been suggested, including dysplasia of the PPTA wall and hemodynamic stress on the PPTA. ${ }^{27)}$ There is no histological evidence supporting the hypothesis that pathological anomalies develop in the PPTA wall. Based on a review of 261 cases with PPTA reported between 1950 and 2003, 39 cases were identified with PPTA aneurysms. ${ }^{20)}$ These aneurysms were located not only at the arterial junction but also on the trunk of the PPTA, and were not always associated with connective tissue disorders such as 
Table 1 Summary of the 20 reported cases of trigeminal carotid fistula

\begin{tabular}{|c|c|c|c|c|c|c|c|c|}
\hline Author (Year) & $\begin{array}{l}\text { Age } \\
\text { (yrs), } \\
\text { Sex }\end{array}$ & Symptoms & Course & Location & Treatment & $\begin{array}{l}\text { Sacrifice } \\
\text { of ICA }\end{array}$ & $\begin{array}{l}\text { Sacrifice } \\
\text { of PTA }\end{array}$ & Result \\
\hline $\begin{array}{l}\text { Enomoto et al. } \\
(1977)^{9)}\end{array}$ & $42, \mathrm{~F}$ & ocular disorder & $\begin{array}{l}\text { spontaneous } \\
\text { (An) }\end{array}$ & $\begin{array}{l}\text { ICA-PPTA } \\
\text { (rt) }\end{array}$ & ICA ligation & yes & no & $\begin{array}{l}\text { cure, } \\
\text { mild } \\
\text { ophthalmo- } \\
\text { plegia }\end{array}$ \\
\hline $\begin{array}{l}\text { Charlin et al. } \\
(1982)^{5)}\end{array}$ & $53, \mathrm{~F}$ & ocular disorder & $\begin{array}{l}\text { spontaneous } \\
\text { (An) }\end{array}$ & $\begin{array}{l}\text { PPTA trunk } \\
\text { (lt) }\end{array}$ & balloon & no & no & cure \\
\hline $\begin{array}{l}\text { Kerber and } \\
\text { Manke } \\
(1983)^{17)}\end{array}$ & $26, \mathrm{M}$ & ocular disorder & spontaneous & $\begin{array}{l}\text { PPTA trunk } \\
\text { (lt) }\end{array}$ & balloon & no & no & cure \\
\hline $\begin{array}{l}\text { Berger and } \\
\text { Hosobuchi } \\
(1984)^{2)}\end{array}$ & $51, \mathrm{~F}$ & ocular disorder & spontaneous & $\begin{array}{l}\text { ICA-PPTA } \\
\text { (lt) }\end{array}$ & $\begin{array}{l}\text { balloon and } \\
\text { surgery }\end{array}$ & yes & yes & $\begin{array}{l}\text { cure, } \\
\text { transient } \\
\text { abducens } \\
\text { palsy }\end{array}$ \\
\hline $\begin{array}{l}\text { Flandroy et al. } \\
(1987)^{10)}\end{array}$ & $35, \mathrm{M}$ & ocular disorder & traumatic & $\begin{array}{l}\text { ICA-PPTA } \\
\text { (rt) }\end{array}$ & balloon & no & no & cure \\
\hline $\begin{array}{l}\text { Debrun et al. } \\
(1988)^{8)}\end{array}$ & $30, \mathrm{M}$ & ocular disorder & traumatic & $\begin{array}{l}\text { ICA-PPTA } \\
\text { (rt) }\end{array}$ & balloon & no & yes & cure \\
\hline $\begin{array}{l}\text { Cheng and Wang } \\
(1990)^{6)}\end{array}$ & $42, \mathrm{M}$ & ocular disorder & traumatic & $\begin{array}{l}\text { ICA-PPTA } \\
\text { (rt) }\end{array}$ & $\begin{array}{l}\text { ICA ligation } \\
\text { and surgery }\end{array}$ & yes & yes & cure \\
\hline \multirow[t]{2}{*}{$\begin{array}{l}\text { Guglielmi et al. } \\
(1990)^{14)}\end{array}$} & $20, \mathrm{M}$ & ocular disorder & traumatic & $\begin{array}{l}\text { PPTA trunk } \\
\text { (rt) }\end{array}$ & refused & - & - & cure \\
\hline & $57, \mathrm{M}$ & ocular disorder & $\begin{array}{l}\text { spontaneous } \\
\text { (An) }\end{array}$ & $\begin{array}{l}\text { ICA-PPTA } \\
\text { (lt) }\end{array}$ & balloon & no & yes & cure \\
\hline $\begin{array}{l}\text { McKenzie et al. } \\
(1996)^{22)}\end{array}$ & $36, \mathrm{M}$ & ocular disorder & $\underset{(\mathrm{An})}{\operatorname{traumatic}}$ & $\begin{array}{l}\text { PPTA trunk } \\
\text { (lt) }\end{array}$ & balloon & no & no & $\begin{array}{l}\text { cure, } \\
\text { mild } \\
\text { ophthalmo- } \\
\text { plegia }\end{array}$ \\
\hline $\begin{array}{l}\text { Bernstein et al. } \\
(1998)^{3)}\end{array}$ & $53, \mathrm{~F}$ & ocular disorder & spontaneous & $\begin{array}{l}\text { ICA-PPTA } \\
\text { (rt) }\end{array}$ & coil (TV) & no & yes & cure \\
\hline $\begin{array}{l}\text { Hurst et al. } \\
(1998)^{16)}\end{array}$ & $62, \mathrm{~F}$ & $\begin{array}{l}\text { bruit, } \\
\text { proptosis, } \\
\text { diplopia }\end{array}$ & spontaneous & $\begin{array}{l}\text { ICA-PPTA } \\
\text { (lt) }\end{array}$ & $\begin{array}{l}\text { coil (TA sinus } \\
\text { packing) }\end{array}$ & no & yes & cure \\
\hline $\begin{array}{l}\text { Masaryk et al. } \\
(1999)^{21)}\end{array}$ & $43, \mathrm{~F}$ & $\begin{array}{l}\text { bruit, } \\
\text { eye symptom }\end{array}$ & spontaneous & $\begin{array}{l}\text { ICA-PPTA } \\
\text { (rt) }\end{array}$ & balloon & no & no & cure \\
\hline $\begin{array}{l}\text { Oka et al. } \\
\qquad(2000)^{24)}\end{array}$ & $58, \mathrm{~F}$ & ocular disorder & spontaneous & $\begin{array}{l}\text { ICA-PPTA } \\
\text { (rt) }\end{array}$ & coil (TV) & no & yes & cure \\
\hline $\begin{array}{l}\text { Cook et al. } \\
(2000)^{7)}\end{array}$ & $83, \mathrm{~F}$ & diplopia & traumatic & $\begin{array}{l}\text { PPTA trunk } \\
\text { (rt) }\end{array}$ & balloon & no & yes & cure \\
\hline $\begin{array}{l}\text { Tokunaga et al. } \\
(2004)^{28)}\end{array}$ & $61, \mathrm{~F}$ & $\begin{array}{l}\text { intracerebral } \\
\text { hemorrhage }\end{array}$ & spontaneous & $\begin{array}{l}\text { PPTA trunk } \\
\text { (lt) }\end{array}$ & coil (TV) & no & no & $\begin{array}{l}\text { cure, } \\
\text { hemiparesis, } \\
\text { dysphasia }\end{array}$ \\
\hline $\begin{array}{l}\text { Chan et al. } \\
\qquad(2006)^{4)}\end{array}$ & $50, \mathrm{~F}$ & ocular disorder & spontaneous & $\begin{array}{l}\text { ICA-PPTA } \\
\text { (rt) }\end{array}$ & coil (TV) & no & no & $\begin{array}{l}\text { cure, } \\
\text { mild } \\
\text { ophthalmo- } \\
\text { plegia }\end{array}$ \\
\hline $\begin{array}{l}\text { Geibprasert et al. } \\
(2008)^{12)}\end{array}$ & $35, \mathrm{~F}$ & ocular disorder & spontaneous & $\begin{array}{l}\text { ICA-PPTA } \\
\text { (rt) }\end{array}$ & $\begin{array}{l}\text { coil (TV) and } \\
\text { glue (TA) }\end{array}$ & no & no & cure \\
\hline $\begin{array}{l}\text { Xin-Ya Qian et al. } \\
(2009)^{30)}\end{array}$ & $62, \mathrm{~F}$ & $\begin{array}{l}\text { eye pain, } \\
\text { chemosis, } \\
\text { ophthalmo- } \\
\text { plegia }\end{array}$ & $\begin{array}{l}\text { spontaneous } \\
\text { (An) }\end{array}$ & $\begin{array}{l}\text { ICA-PPTA } \\
\text { (rt) }\end{array}$ & coil (TV) & no & no & cure \\
\hline Present case & $60, \mathrm{~F}$ & $\begin{array}{l}\text { bruit, } \\
\text { abducens } \\
\text { palsy }\end{array}$ & $\begin{array}{l}\text { spontaneous } \\
\text { (An) }\end{array}$ & $\begin{array}{l}\text { PPTA trunk } \\
\text { (lt) }\end{array}$ & coil (intra-An) & no & no & cure \\
\hline
\end{tabular}

An: aneurysm, F: female, ICA: internal carotid artery, M: male, PPTA: persistent primitive trigeminal artery, TA: transarterial, TV: transvenous.

Ehlers-Danlos syndrome. The site of most reported PPTA aneurysms has been the curved trunk of the PPTA, suggesting that high hemodynamic stress initiates aneurysm formation. ${ }^{27)}$ In our case, the aneurysm was also situated on the curved trunk of the PPTA. Postoperative MR angiography indicated hypoplasia of basilar artery. Therefore, the findings in this case supported hemodynamic stress as the cause of the PPTA.

\section{References}

1) Barrow DL, Spector RH, Braun IF, Landman JA, Tindall SC, Tindall GT: Classification and treatment of spontaneous carotid-cavernous sinus fistulas. J Neurosurg 62: 248-256, 1985

2) Berger MS, Hosobuchi Y: Cavernous sinus fistula caused by intracavernous rupture of a persistent primitive trigeminal 
artery. Case report. J Neurosurg 61: 391-395, 1984

3) Bernstein K, Teitelbaum GP, Herman B, Giannotta SL: Coil embolisation of a trigeminal-cavernous fistula. AJNR Am J Neuroradiol 19: 1953-1954, 1998

4) Chan YL, Shing KK, Wong KC, Poon WS: Transvenous embolisation of a carotid-trigeminal cavernous fistula. Hong Kong Med J 12: 310-312, 2006

5) Charlin JF, Clavier E, Thiebot J, Brasseur G, Langlois J: [Cavernous fistula caused by rupture of an aneurysm of the trigeminal artery. Case report]. Rev Otoneuroophtalmol 54: 249-254, 1982 (French)

6) Cheng WC, Wang AD: Carotid-cavernous sinus fistula associated with a primitive trigeminal artery. Neurosurgery 27: 802-805, 1990

7) Cook BE Jr, Leavitt JA, Dolan JW, Nichols DA: Carotid cavernous fistula associated with persistent primitive trigeminal artery. J Neuroophthalmol 20: 264-265, 2000

8) Debrun GM, Davis KR, Nauta HJ, Heros RE, Ahn HS: Treatment of carotid cavernous fistulae or cavernous aneurysms associated with a persistent trigeminal artery: report of three cases. AJNR Am J Neuroradiol 9: 749-755, 1988

9) Enomoto T, Sato A, Maki Y: Carotid-cavernous sinus fistula caused by rupture of a primitive trigeminal artery aneurysm. Case report. J Neurosurg 46: 373-376, 1977

10) Flandroy P, Lacour P, Marsault C, Stevenaert A, Collignon J: The intravascular treatment of a cavernous fistula caused by rupture of a traumatic carotid trigeminal aneurysm. Neuroradiology 29: 308-311, 1987

11) Freitas P, Aquini M, Chemale I: Persistent primitive trigeminal artery aneurysm. Surg Neurol 26: 373-374, 1986

12) Geibprasert $S$, Jiarakongmun $P$, Krings $T$, Pongpech S: Trigeminal fistula treated by combined transvenous and transarterial embolisation. Acta Neurochir (Wien) 150: 583-588, 2008

13) Goto K, Hieshima GB, Higashida RT, Halbach VV, Bentson JR, Mehringer CM, Pribram HF: Treatment of direct carotid cavernous sinus fistulae. Various therapeutic approaches and results in 148 cases. Acta Radiol Suppl 369: 576-579, 1986

14) Guglielmi G, Vinuela F, Dion J, Duckwiler G, Cantore G, Delfini R: Persistent primitive trigeminal artery-cavernous sinus fistulas: report of two cases. Neurosurgery 27: 805-808, 1990

15) Halbach VV, Higashida RT, Hieshima GB, Hardin CW, Yang PJ: Transvenous embolization of direct carotid cavernous fistulas. AJNR Am J Neuroradiol 9: 741-747, 1988

16) Hurst RW, Howard RS, Zager E: Carotid cavernous fistula associated with persistent trigeminal artery: endovascular treatment using coil embolisation. Skull Base Surg 8: 225-228, 1998

17) Kerber CW, Manke W: Trigeminal artery to cavernous sinus fistula treated by balloon occlusion. Case report. J Neurosurg 58: 611-613, 1983

18) Kobayashi N, Miyachi S, Negoro M, Suzuki O, Hattori K, Kojima T, Yoshida J: Endovascular treatment strategy for direct carotid-cavernous fistulas resulting from rupture of intracavernous carotid aneurysms. AJNR Am J Neuroradiol 24: 1789-1796, 2003

19) Lewis AI, Tomsick TA, Tew JM Jr: Management of 100 consecutive direct carotid-cavernous fistulae: results of treatment with detachable balloons. Neurosurgery 36: 239-244, 1995

20) Li MH, Li WB, Pan YP, Fang C, Wang W: Persistent primitive trigeminal artery associated with aneurysm: report of two cases and review of the literature. Acta Radiol 45: 664-668, 2004

21) Masaryk TJ, Perl J 2nd, Wallace RC, Magdinec M, Chyatte D: Detachable balloon embolisation: concomitant use of a second safety balloon. AJNR Am J Neuroradiol 20: 1103-1106, 1999

22) McKenzie JD, Dean BL, Flom RA: Trigeminal-cavernous fistula: Saltzman anatomy revisited. AJNR Am J Neuroradiol 17: 280-282, 1996

23) Naesens R, Mestdagh C, Breemersch M, Defreyne L: Direct carotid-cavernous fistula: a case report and review of the literature. Bull Soc Belge Ophtalmol (299): 43-54, 2006

24) Oka Y, Sadamoto K, Tagawa M, Kumon Y, Sakaki S, Fujita M: Transvenous embolization of carotid-cavernous sinus fistula associated with a primitive trigeminal artery-case report. Neurol Med Chir (Tokyo) 40: 61-64, 2000

25) O'uchi E, O'uchi T: Persistent primitive trigeminal arteries (PTA) and its variant (PTAV): analysis of 103 cases detected in 16,415 cases of MRA over 3 years. Neuroradiology 52: 1111-1119, 2010

26) Salas E, Ziyal IM, Sekhar LN, Wright DC: Persistent trigeminal artery: an anatomic study. Neurosurgery 43: 557-561, 1998

27) Takase T, Tanabe H, Kondo A, Nonoguchi N, Tane K: Surgically treated aneurysm of the trunk of the persistent primitive trigeminal artery-case report. Neurol Med Chir (Tokyo) 44: 420-423, 2004

28) Tokunaga K, Sugiu K, Kameda $M$, Sakai K, Terasaka K, Higashi T, Date I: Persistent primitive trigeminal arterycavernous sinus fistula with intracerebral hemorrhage: endovascular treatment using detachable coils in a transarterial double-catheter technique. Case report and review of the literature. J Neurosurg 101: 697-699, 2004

29) van Rooij WJ, Sluzewski M, Beute GN: Ruptured cavernous sinus aneurysms causing carotid cavernous fistula: incidence, clinical presentation, treatment, and outcome. AJNR Am J Neuroradiol 27: 185-189, 2006

30) Xin-Ya Qian C, Ares C, Codere F, Tampieri D: Rupture of an aneurysm of the persistent trigeminal artery presenting as a carotid-cavernous sinus fistula. Orbit 28: 275-280, 2009

Address reprint requests to: Masahiro Yoshida, MD, Department of Neurosurgery, Osaki Citizen Hospital, 2-3-10 Senjuji-cho, Osaki, Miyagi 989-6183, Japan.

e-mail:m-ysd@ya2.so-net.ne.jp 